\title{
WARTA FARMASI
}

https://poltek-binahusada.e-journal.id/wartafarmasi

Volume 8 | Nomor 2 | Oktober | 2019

ISSN: 2089-712X

\section{Gambaran Kesehatan Gingivitis Pengguna Alat Ortodontik Yang Memasang Pada Tukang Gigi}

\section{Health gingivitis of orthodontic appliance on private dental artisans}

\author{
Rahminingrum Pujirahayu*, Adriatman Rasak, Mery Erfiani \\ Politeknik Bina Husada Kendari Program Studi D-III Kesehatan Gigi \\ J1. Sorumba No.17, Kendari, Sulawesi Tenggara \\ Email; rahmipoliteknik@gmail.com*, meryerfiani@yahoo.co.id.
}

\begin{abstract}
ABSTRAK
Perawatan gigi ditentukan oleh kesehatan gingival. Rendahnya pemeliharaan kesehatan gigi dan mulut akan mempengaruhi kesehatan jaringan periodontal. Pemakaian Alat ortodontik berhubungan dengan peningkatan kejadian gingiva dan perdarahan. Penelitian ini bertujuan untuk menggambarkan gingiva pengguna alat ortodontik yang memasang pada tukang gigi swasta. Jenis penelitian ialah deskriptif dengan desain cross sectional. Penelitian dilakukan di salah satu praktek tukang gigi swasta dan rumah. Responden penelitian berjumlah 40 orang. Teknik pengambilan sampel ialah total sampling. Analisis data secara deskriptif dan dijabarkan dalam bentuk narasi. Hasil penelitian menunjukkan pengguna alat ortondontik yaitu perempuan sebanyak 29 orang ( $72,5 \%)$, dan laki-laki sebanyak 11 orang $(27,5 \%)$. Kejadian gingivitas berdasarkan umur paling banyak pada usia 7-12 tahun sebanyak 9 orang $(27,5 \%)$ dan 13 - 18 sebanyak 14 orang (43,75\%). Kejadian gingivitis berdasarkan jenis kelamin, laki-laki sebanyak 10 orang $(90,9 \%)$ dan perempuan sebanyak 22 orang $(75,86 \%)$.
\end{abstract}

Kata kunci ; , tukang gigi, gingivitis, gigi dan mulut

\begin{abstract}
Orthodontic treatment is determined by gingival health. The low maintenance of oral health will affect the health of periodontal tissue. The use of orthodontic devices is associated with an increased incidence of gingiva and bleeding. This study aims to describe the gingivitis of orthodontic appliance users who install it on private dental artisans. This type of research is descriptive with a cross-sectional design. The study was conducted at one of the private and home dental practice. Research respondents numbered 40 people. The sampling technique is total sampling. Data analysis is descriptive and described in narrative form. The results showed orthodontic device users, namely 29 women (72.5\%), and 11 men (27.5\%). The incidence of gingivitis based on age at most at the age of 7-12 years was 9 people (27.5\%)
\end{abstract}


and 13-18 were 14 people (43.75\%). The incidence of gingivitis based on sex, men as many as 10 people (90.9\%) and women as many as 22 people (75.86\%).

Keywords; Orthodontics, dental artisan, gingivitis, teeth, and mouth

\section{PENDAHULUAN}

Dewasa ini, diberbagai negara khususnya di Indonesia biaya pelayanan kesehatan semakin meningkat (Musdalipah, dkk, 2018). Salah satu pelayanan kesehatan yang membutuhkan biaya perawatan secara berkesinambungan ialah penyakit gigi dan mulut. Gingivitis dan periodontitis merupakan penyakit keradangan jaringan periodontal yang banyak diderita masyarakat Indonesia. Rendahnya pemeliharaan kesehatan gigi dan mulut akan berdampak terhadap kesehatan jaringan periodontal.

Prevalensi angka kejadian kelainan susunan gigi dan pengatupan rahang di Indonesia konon mencapai $80 \%$ dan menempati urutan ketiga setelah karies gigi dan penyakit periodontal Kebutuhan akan estetika semakin meningkat seiring dengan kebutuhan kesehatan mulut. Fenomena ini membuktikan banyaknya pasien yang datang ke klinik gigi (Guarnieri, 2013). Kesuksesan perawatan dipengaruhi oleh berbagai faktor seperti kesehatan jaringan periodontal, oral hygiene, dan kekuatan mekanik ortodontik (Wiwekowati, 2017).

Perawatan ortodontik bertujuan untuk mendapatkan oklusi normal, meningkatkan kesehatan periodontal, kesehatan gigi dan estetika wajah. Peningkatan minat perawatan ortodontik karena tingginya prevalensi maloklusi. Saat ini, banyak orang menggunakan peralatan ortodontik cekat atau dapat dilepas. Pengguna alat $\mathrm{k}$ sangat rentan terhadap kebersihan mulut yang buruk (Herwanda, 2016; Baheti, dkk, 2014, oley, dkk, 2014, Galag, 2015).

Kesehatan periodontal adalah faktor penting yang digunakan untuk mengevaluasi keberhasilan perawatan ortodontik. Komplikasi periodontal dilaporkan sebagai salah satu efek samping paling umum yang terkait dengan ortodontik. Komplikasi periodontal yang terkait dengan ortodontik adalah gingivitis, periodontitis, resesi atau hipertrofi gingiva, dan kehilangan tulang alveolar. Plak adalah faktor yang paling penting dalam inisiasi, perkembangan, dan kekambuhan penyakit periodontal (Baheti, dkk, 2014; Alfuriji, 2014). Penumpukan plak gigi memicu terbentuknya karies gigi yang dapat menimbulkan masalah gigi dan mulut (Wulaisfan dan Musdalipah, 2018).

Penggunaan alat ortodontik mengakibatkan buruknya kondisi oral hygiene. Telah dilaporkan bahwa sedikitnya 3 pasien memiliki oral hygiene yang buruk mengalami perpanjangan waktu perawatan 1,2 sampai 2,2 bulan (Skidmore, dkk, 2006). Hasil penelitian Wijayanti dkk (2014), menunjukkan subyek 
anak SD di Jakarta usia 9-11 tahun diperoleh $76,5 \%$ membutuhkan perawatan ortodontik . Berdasarkan survey awal yang dilakukan di salah satu praktek tukang gigi di wilayah Kota Kendari, ditemukan ada beberapa pasien yang mengalami penyakit gingivitis setelah mendapatkan perawatan orthodontik. Berdasarkan hal tersebut maka penulis berinisiatif untuk mengangkat judul mengenai " Gambaran kesehatan Gingivitis Pengguna alat Orthodontik yang memasang pada tukang gigi”.

\section{METODE}

Metode penelitian ialah deskriptif dengan pendekatan cross sectional. Penelitian dilakukan pada praktek tukang gigi swasta di wilayah kota Kendari. Sampel penelitian sebanyak 40 orang. Teknik pengambilan sampel adalah total sampling. Data dianalisis secara deskriptif dan dijabarkan dalam bentuk narasi.

\section{Alat dan Bahan \\ Alat yang digunakan berupa Pinset, Mouth mirror, Excavator, Sonde, Mouth gag, sedangkan Bahan ialah kapas, alkohol, lembaran observasi dan oral diagnostic.}

\section{Prosedur Penelitian}

a. Tahap persiapan meliputi ; Mempersiapkan instrument yang sudah disterilkan dan Mempersiapkan lembar penilaian.

b. Tahap penelitian meliputi ; dianjurkan untuk membuka mulut dan memeriksa daerah gingival dengan melihat tanda klinis gingivitis, untuk mengetahui ada tidaknya gingivitis.

c. Kriteria Objektif :

Jika 0 : tidak ada gingivitis.

Jika 1 : ada gingivitis

\section{HASIL dan PEMBAHASAN}

Penelitian dilaksanakan pada bulan Mei sampai Juli 2019 di salah satu Praktek tukang gigi swasta pada pasien yang menggunakan alat Orthodontik. Berdasarkan hasil yang diperoleh sebagai berikut ;

\section{Karakterestik Responden}

\section{a. Distribusi Responden Berdasarkan}

\section{Umur}

Umur adalah usia responden pada saat penelitian dilaksanakan dalam hitungan tahun, yang dibagi menjadi enam pengelompokkan umur yakni 7-12 tahun, 13-18 tahun, 19-24 tahun, 25-30 tahun, 31-36 tahun, 37-42 tahun. 
Tabel 1. Distribusi Responden Berdasarkan Kelompok Umur

\begin{tabular}{cccc}
\hline No & Umur & n & Persentase (\%) \\
\hline $\mathbf{1}$ & $7-12$ Thn & 9 & 22,5 \\
$\mathbf{2}$ & $13-18$ Thn & 16 & 40 \\
$\mathbf{3}$ & $19-24 \mathrm{Thn}$ & 4 & 10 \\
$\mathbf{4}$ & $25-30 \mathrm{Thn}$ & 4 & 10 \\
$\mathbf{5}$ & $31-36 \mathrm{Thn}$ & 4 & 10 \\
$\mathbf{6}$ & $37-42$ Thn & 3 & 7,5 \\
& Jumlah & 40 & 100 \\
\hline
\end{tabular}

Sumber : Data Primer 2019

Tabel 1 menunjukan distribusi frekuensi tertinggi pada kelompok umur 13- terendah 18 tahun yaitu sebanyak 16 responden $(40 \%)$, sementara distribusi frekuensi pada kelompok umur 37-42 tahun yaitu sebanyak 3 responden $(7,5 \%)$. Penggunaan alat ortodontik cekat berkisar usia remaja hingga usia dewasa. Pada usia remaja, identifikasi masalah mengenai rongga mulut lebih mudah. Pada usia ini seseorang sudah berkomunikasi secara lancar, selain itu pada usia ini sudah berada dalam periode gigi tetap dan tumbuh kembang yang optimal (Sutardi, 2010).

\section{b. Distribusi Responden Berdasarkan Jenis Kelamin}

Karakteristik responden berdasarkan jenis kelamin dapat dilihat pada tabel 2:

Tabel 2. Distribusi Responden Berdasarkan jenis Kelamin

\begin{tabular}{cccc}
\hline No & Jenis Kelamin & n & Persentase (\%) \\
\hline $\mathbf{1}$ & Laki-Laki & 11 & 27,5 \\
$\mathbf{2}$ & Perempuan & 29 & 72,5 \\
& Jumlah & 40 & 100 \\
\hline
\end{tabular}

Sumber : Data Primer 2019

Berdasarkan tabel 2 menunjukan dari 40 responden jenis kelamin perempuan sebanyak 29 responden ( $72,5 \%$ ), dan jenis kelamin laki-laki sebanyak 11 responden (27,5\%). Penelitian Galag dkk (2015), bahwa perbandingan pasien yang memakai pada perempuan SMA di Menado sebesar
86\% sedangkan pasien laki-laki sebesar 14\% . Hasil penelitian Wiwekowati (2017), karakteristik jenis kelamin perempuan 15 pasien (60\%) lebih banyak dibandingkan dengan laki-laki 10 pasien (40\%). Hasil penelitian sejalan dengan Marchellina, et al (2016) bahwa jenis kelamin perempuan 
(80\%) paling banyak menggunakan alat ortodontik cekat di SMA Neg.1 Manado.

Fenomena penggunaan alat menunjukkan pola bahwa responden perempuan memiliki kebutuhan yang lebih tinggi terhadap penampilan atau estetika. Perempuan lebih percaya diri ketika penampilan gigi geliginya lebih rapi. Penampilan atau estetika juga merupakan salah satu faktor yang memengaruhi seseorang menggunakan alat ortodontik cekat. Perempuan lebih tidak percaya diri ketika terdapat malposisi pada gigi yang mengurangi nilai estetika pada dirinya, sedangkan pada laki-laki hal ini tidak terlalu menjadi perhatian, sehingga banyak pengguna alat ortodontik cekat ialah perempuan (Momongan R, 2014).

\section{c. Distribusi kejadian penyakit gingivitis berdasarkan umur}

Tabel 3. Distribusi kejadian penyakit gingivitis berdasarkan umur

\begin{tabular}{cccccc}
\hline No & \multirow{2}{*}{$\begin{array}{c}\text { Umur } \\
\text { (Tahun) }\end{array}$} & \multicolumn{4}{c}{ Gejadian Penyakit Gingivitis } \\
\cline { 3 - 6 } & & $\mathrm{n}$ & $\%$ & $\mathrm{n}$ & $\%$ \\
$\mathbf{1}$ & $7-12$ & 9 & 28,12 & 0 & 0 \\
$\mathbf{2}$ & $13-18$ & 14 & 43,75 & 2 & 25 \\
$\mathbf{3}$ & $19-24$ & 4 & 12,5 & 0 & 0 \\
$\mathbf{4}$ & $25-30$ & 3 & 9,37 & 1 & 12,5 \\
$\mathbf{5}$ & $31-36$ & 1 & 3,13 & 3 & 37,5 \\
$\mathbf{6}$ & $37-42$ & 1 & 3,13 & 2 & 25 \\
& Jumlah & 32 & 100 & 8 & 100 \\
\hline
\end{tabular}

Sumber : Data Primer, 2019

Tabel 3 menunjukkan kejadian penyakit gingivitis lebih banyak terjadi pada usia 13 18 tahun yaitu sebesar $43,75 \%$. Secara keseluruhan jumlah kejadian gingivitis sebanyak 32 orang. Penelitian (Diah, dkk, 2019) pengguna alat ortodontik cekat yang berjenis kelamin perempuan lebih banyak memiliki status kesehatan ginggiva dengan kriteria peradangan ringan, yaitu sebanyak 13 orang $(19,40 \%)$. Pengguna alat ortodontik cekat yang berusia 21 tahun, lebih banyak mengalami status kesehatan ginggiva pada kriteria peradangan ringan, yaitu sebanyak 6 orang $(8,95 \%)$. 


\section{d. Distribusi Kejadian Gingivitis Berdasarkan Jenis Kelamin}

Tabel 4. Distribusi Kejadian Gingivitis Berdasarkan Jenis Kelamin

\begin{tabular}{cccccc}
\hline \multirow{2}{*}{ No } & \multirow{2}{*}{ Kejadian Gingivitis } & \multicolumn{2}{c}{ Laki-laki } & \multicolumn{2}{c}{ Perempuan } \\
\cline { 3 - 6 } $\mathbf{1}$ & Gingivitis & 10 & 90,9 & 22 & 75,86 \\
$\mathbf{2}$ & Tidak Gingivitis & 1 & 9,1 & 7 & 24,14 \\
& Jumlah & 11 & 100 & 29 & 100 \\
\hline
\end{tabular}

Sumber : Data Primer, 2019

Kejadian gingivitis lebih banyak terjadi pada perempuan (22\%) dibanding laki-laki $(10 \%)$. Hal ini terjadi karena pemasangan alat pada tukang gigi kurang mendapatkan pengontrolan kesehatan gigi, kurangnya motivasi dan saran yang diberikan mengenai menjaga kebersihan rongga mulut. Hal ini tentunya berbeda bila dilakukan di klinik yang ditangani oleh dokter gigi yang profesional. Dokter gigi akan memberikan informasi mengenai metode pemeliharaan kebersihan yang benar serta penggunaan alat bantu oral hygiene yang sehingga membantu menghilangkan plak dan mengurangi peradangan ginggiva (Prasanti dan Santosa, 2016).

Gingivitis yang terjadi pada usia remaja kemungkinan dapat diakibatkan oleh faktor oral hygiene. Pada usia ini kebiasaan menjaga oral hygiene sedang terbentuk, dan pada usia remaja ini masih memerlukan pengawasan dan motivasi agar dapat menjaga oral hygiene-nya (Diah, dkk, 2019). Penelitian Ana (2012) menunjukkan penggunaan alat ortodontik cekat meningkatkan akumulasi plak sehingga menyebabkan terjadinya hiperplasia gingiva dan poket pada gingival. Tanya, dkk (2010) juga menyimpulkan bahwa terjadi inflamasi kronis pembesaran gingiva disertai akumulasi plak yang tinggi pada pengguna alat ortodontik cekat.

Kesehatan gingiva merupakan faktor yang harus diperhatikan dan dijaga oleh pengguna alat ortodontik cekat. Gingivitis bila dibiarkan terus menerus akan menyebabkan periodontitis, halitosis, poket, gigi goyang, dan gigi lepas (Marchellina, et al 2016).

\section{KESIMPULAN}

Gambaran kesehatan gingivitis pengguna alat ortondontik yang memasang ditukang gigi yaitu kejadian gingivitas berdasarkan umur paling banyak pada usia 7-12 tahun sebanyak 9 orang $(27,5 \%)$ dan 13 - 18 sebanyak 14 orang $(43,75 \%)$. Status gingivitis paling banyak di alami oleh perempuan 
sebanyak 22 orang $(75,86 \%)$ dan laki-laki sebanyak 10 orang $(90,9 \%)$.

\section{UCAPAN TERIMA KASIH}

Ucapan terima kasih ditujukan pada Kementerian Riset Teknologi dan Pendidikan Tinggi yang telah membiayai penelitian ini hingga selesai pada skim Penelitian Dosen Pemula pendanaan tahun 2019.

\section{DAFTAR PUSTAKA}

Ana C, Amoras A. 2012. The Impact of Orthodontik Treatment on Periodontal Support Loss. Dental Press J.Orthod. vol. 17 no. 1 Maringa 2012. Available from : http//dx.doi.org/10.1590/S21769451 2012000100002.

Alfuriji S. Nora, A. Nasir, A. Ali. Moatazbellah, A. Nasser A. Amrita, G. Review Article :The Effect of Orthodontic Therapy on Periodontal Health: A Review of the Literature. International Journal of Dentistry. 2014; 1-8.

Baheti, M.J., Nandlal G.T., Saurav D.B. Oral Health in Orthodontic treatment: Preventive and Innovative Approach. journal of dentofacial sciences. 2014; 3(3): 39-46.

Diah, Ni Made Yeni Septianing, Putu Ika Anggaraeni, and Louise Cinthia Hutomo. 2019. "Status Kesehatan Ginggiva Pengguna Alat Ortodontik Cekat Pada Mahasiswa Fakultas Kedokteran Universitas Udayana, Denpasar, Bali.” Intisari Sains Medis 10(1): 125-30.

Guarnieri, S. 2013. An esthetic concern leads the way to improved oral health. Compend Contin Educ Dent. 34(8) ; 606 -20 .
Galag, C.A., Anadita, P.S., Waworuntu, O. 2015. Status Kebersihan Mulut Pada Pengguna Alat Ortodont Cekat Berdasarkan Oral Hygiene Index Simplified di Sekolah Menengah atas Negeri 1 Manado. Jurnal eGigi. 3 (2) : 298-301.

Herwanda, Rafinus A., Lindawati. Pengetahuan Remaja Usia 15-17 Tahun di SMAN 4 Kota Bansa Aceh Terhadap Efek Samping Pemakaian Alat Cekat. Journal of Syiah Kuala Dentistry Society. 2016; 1(1): 79. 2.

Musdalipah; Setiawan, MA; Santi, E. 2018. analisis efektivitas biaya antibiotik sefotaxime dan gentamisin penderita pneumonia pada balita di RSUD Kabupaten Bombana Provinsi Sulawesi Tenggara. Jurnal Ilmiah Ibnu Sina, 3(1), 1-11. Retrieved from http://jiis.akfarisfibjm.ac.id/index.php/JIIS/article/view $\underline{104}$.

Marchellina, G, A, Anindita, Olivia, Waworuntu, 2016, Status Kesehatan Gingiva pada Pengguna Alat $k$ Cekat di SMA Neg.1 Manado, Pharmacon, Jurnal Ilmiah farmasi UNSTRAT, 5(1) : 150 - 157.

Oley, A.B., Anindita, Michael. A.L. Kebutuhan Perawatan Berdasarkan Index of Orthodontic Treatment Need pada Usia Remaja 15-17 Tahun. Journal e-GiGi. 2015; 3(2) : 292.

Prasanti A, Santosa O. 2016. Perbedaan Indeks Periodontal dan Skor Pembesaran Gingiva Kelompok Pemakai Dan Bukan Pemakai Pesawat Cekat, Semarang, Jurnal Kedokteran Dipenogoro.5(1): 1-8.

Skidmore, KJ, Brook KJ, Thomson WM, Harding WJ. 2006. Factors influecing treatment time in orthodontic ptients. American journal of orthodontic and 
dentofacial orthopedics ; official publication of the american associatio $n$ of orthodontist, its constituent societies, and the american board of orthodontic, 129(2) : 230-8.

Sutardo I. 2011. Pertimbangan dan Permasalahan pemakaian Alat interseptik Ortodonsi Secara Dini pada Anak Masa Tumbuh Kembang. J.K.G Unej; 8(1):1-10.

Tanya J, Mahalinga BK, Subraya BG, Jothi MV. 2013. Chronic Inflamatory Gingival Enlargemen Associated with Orthodontic
Therapy. J Dent Hyg .Vol. 87 no. 1 19-23.

Wulaisfan, R., \& Musdalipah. (2018). Aktivitas ekstrak kulit bawang merah (allium ascalonicum 1.) Terhadap pertumbuhan bakteri Streptococcus mutans. Jurnal Ilmiah Farmasyifa, 1(2), 126-132.

Wijayanti, P., Krisnawati, Ismah, N. 2014. Gambaran Maloklusi dan Kebutuhan Perawatan Pada Anak Usia 9-11 Tahun (Studi pendahuluan di SD AtTaufiq, Cempaka Putih, Jakarta). Jurnal PDGI. 63:1 (25-29). 